\title{
Timing of the Baltic Ice Lake in the eastern Baltic
}

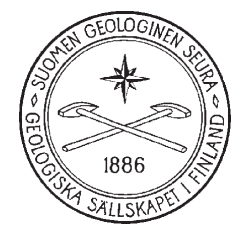

\author{
JÜri VassiljeV and Leili SaARse \\ Institute of Geology at Tallinn University of Technology, \\ Ehitajate tee 5, 19086 Tallinn, Estonia
}

\begin{abstract}
A shoreline database for the Baltic, covering the Late Weichselian and Holocene, was compiled. The database includes about 1600 sites from Estonia, Latvia, Lithuania, Finland, NW Russia, Poland, Sweden and was used to create a GIS-based palaeogeographical reconstructions on the development of the Baltic Ice Lake (BIL). The formation of the highest shoreline of the BIL in Estonia was connected with the development of the Pandivere ice marginal zone (Estonia) and the lowest with the Salpausselkä ice-marginal formations (Finland). There was a well-accepted knowledge that the Pandivere ice marginal zone correlates with the Neva ice marginal zone in NW Russia dated to 13300 cal yr BP. Recent studies of the late glacial sites in northern Estonia indicate that the age of the Pandivere ice marginal zone and hence the highest shoreline of the BIL $A_{1}$ is about $13800-14000$ cal yr BP. It was followed by the BIL stage $A_{2}$, which formed in front of the Palivere ice marginal belt about $13200-13500$ cal yr BP. The final drainage of the BIL took place about 11650 cal yr BP. The timing of the BIL stages was derived from AMS $-{ }^{14} \mathrm{C}$ dates and correlated with varve chronology, OSL and ${ }^{10} \mathrm{Be}$ dates.
\end{abstract}

Keywords: paleogeography, sea-level changes, Baltic Ice Lake, ice-marginal features, absolute age, C-14, deglacation, Quaternary, Estonia

Corresponding author email: vassilje@gi.ee

Editorial handling: Joonas Virtasalo

\section{Introduction}

The last termination of the Scandinavian Ice Sheet (SIS) produced a large volume of meltwater that led to the formation of water bodies, like the Baltic Ice Lake (BIL), in front of the retreating glacier. The concept of the BIL was defined by Munthe (1910), who proposed that during the lategacial an ice-dammed lake was dammed up in the Baltic Sea basin, when the ice margin located at the Central Swedish Moraine belt. As the ice retreated from this moraine belt the water level dropped (Billingen drainage) to the ocean level and the Yoldia Sea was formed. Ramsay (1917) studied the Salpausselkä area in Finland and showed that the highest shoreline there belongs to the BIL. Studying 
shorelines in Estonia and Ingermanland (NW Russia) he found that the highest shores there are older than the BIL ones in Finland and proposed that they belong to the local ice lakes (Ramsay 1928, 1929). Since that the concept of the lateglacial shorelines, divided between local ice lakes and BIL, was used in Estonia (Pärna, 1960; Kessel \& Raukas, 1979) and in Ingermanland (Markov, 1931; Kvasov, 1979), according to which the local ice lakes developed during the Allerød and BIL existed during the Younger Dryas. In Latvia the onset of the BIL was considered to start already in Allerød (Grinbergs, 1957; Veinbergs, 1979), at the same time of existence of the so-called local ice lakes in Estonia. Further south in Lithuania the onset of the BIL is proposed to occur even in the Older Dryas (Gudelis, 1979).

Later Hyyppä (1943) and Sauramo (1958) suggested that connection to the White Sea existed via Karelia and they introduced the concept of the Lateglacial \Gothiglacial Yoldia Sea, which existed before the BIL and was assumed to represent the low ocean level. Pärna (1960) adapted this concept, suggesting that low water level (Palivere-Nómme ice lake) existed before the BIL. Kvasov (1979), however, showed that connection with the White Sea was very unlikely as the eastern Finland and Karelia were covered by a continental ice sheet. The idea of the White Sea connection resulted from the misinterpretation of the pollen zones, which were assumed to be diachronous, but radiocarbon dating showed that they were metachronous and deglaciation of the eastern Finland and Karelia took place much later (Hyvärinen, 1973). More recently, Saarnisto et al. (1995) showed that the thresholds between the Baltic and White Sea seem to be too high for a sea connection. However, that low water level stage remained in use in Estonia, despite the fact that there was no physical explanation for that.

The end of the BIL is connected with the Billingen drainage in Sweden, when the water level drop about $25 \mathrm{~m}$ occurred at $11690 \pm 10$ varve yr BP (Andrén et al., 2002) or $11653 \pm 99$ cal yr BP (Rasmussen et al., 2006). However, the onset and hence the duration of the BIL in the eastern part of the Baltic varies significantly due to different deglaciation chronologies and therefore complicates the correlation of shoreline data between different countries in the eastern Baltic.

Björck (1995) proposed that BIL started when the Öresund threshold was closed resulting the water level rise in the Baltic basin above the sea level. That defines the hydrological reason of the BIL development. However, the timing of that event is poorly dated and according to the present knowledge it occurred about $14000 \mathrm{cal} \mathrm{yr} \mathrm{BP} \mathrm{(ca}$ $12000{ }^{14} \mathrm{C}$ yr BP) when the sea level (and also BIL) at Öresund was about $7 \mathrm{~m}$ b.s.l. (Björck, 1995).

Primarily the shore displacement of the BIL was solely distinguished on the base of the morphological evidence and pollen zones have been used as a time markers (Ramsay, 1929; Pärna, 1960). Since those first studies methodology of shoreline reconstruction has been significantly developed, especially during the last 10 years (e.g., Leverington et al., 2002; Jakobsson et al., 2007; Rosentau et al., 2007; Vassiljev et al., 2011). Miidel (1995) summarized geomorphological and geochronological data on more than 200 shoreline sites in Estonia and applied trend surface analyses to reconstruct the isobases of the BIL, Ancylus Lake and Litorina Sea. Saarse et al. (2003) examined the Baltic Sea shoreline data statistically using a point kriging interpolation. The shoreline database was created and published (Vassiljev et al., 2005; Saarse et al., 2007) enabling us to expand the reconstructions to the neighbouring areas (Rosentau et al., 2007, 2008; Vassiljev et al., 2011). But the chronology of the deglaciation and the timing of the BIL stages associated with the ice marginal belts is still debated because different dating methods, as OSL, cosmogenic ${ }^{10} \mathrm{Be}$, varve chronology and AMS $-{ }^{14} \mathrm{C}$ dates produced different ages (Raukas, 2004; Saarse et al., 2009, 2012a, b; Hang et al., 2011; Kalm et al., 2011).

The aim of the current study was to enhance our knowledge about the development of the BIL in the eastern Baltic, specially the timing, considering newly obtained AMS $-{ }^{14} \mathrm{C}$ dates (Saarse et al., 2009; Amon \& Saarse, 2010; Saarse et al. 2012a, b), which promoted to elaborate the age of the ice marginal belts and associated with those proglacial lakes. 


\section{Material and methods}

To improve shoreline reconstructions a uniform shoreline database (Vassiljev et al., 2005; Saarse et al., 2007) was created, covering about 1600 lateglacial shoreline sites and ca 150 radiocarbon dates. The proxies were derived from the different published and unpublished sources of the Estonia (Vassiljev et al., 2005; Saarse et al., 2007), Latvia (Grinbergs, 1957), NW Russia (Markov, 1931), southern Finland (Donner, 1978), Lithuania (Gelumbauskaitë \& Šeèkus, 2005; Bitinas et al., 2002), Poland (Uścinowicz, 2006) and Sweden (Agrell, 1976; Svensson, 1989). Statistical analyses showed that roughly half of collected data does not match the water level reconstruction requirements due do in accurate elevations or erroneous correlation of different shorelines. The reliability of shoreline data was verified by different methods, like sites with altitudes not matching with neighbouring sites were eliminated. Then, point kriging interpolation with linear trend was used to interpolate the water level surfaces. Residuals, the difference between the actual site altitude and the interpolated surface, were calculated and sites with residuals more than $\pm 1 \mathrm{~m}$ were discarded. BIL shorelines and bathymetry were reconstructed using GIS techniques, where the interpolated water level surfaces were removed from the Shuttle Radar Topography Mission - SRTM (Jarvis et al., 2008) and for southern Finland from GTOPO30 data (US Geological Survey, 1996). Baltic Sea topography data were derived from Seifert et al. (2001).

The radiocarbon chronology is based on the calibration of the radiocarbon dates using the IntCal09 calibration dataset (Reimer et al., 2009) and the $\mathrm{OxCal} 4.1$ program depositional model (Bronk Ramsey, 2008, 2009). Calibrated ages are given as weighted averages with 2 sigma error bars. All the ${ }^{14} \mathrm{C}$ ages are rounded to the nearest 50 and error to the nearest 10 .

\section{Modelling results}

In the following we present reconstruction on the BIL spatial and temporal distribution over the whole
Baltic region. As there is lack of proxy data suitable for the modelling from the southern Baltic, we consider these reconstructions as preliminary.

\subsection{BIL 14000 cal yr BP $\left(A_{1}\right)$}

Reconstruction shows that the BIL water level in front of the ice margin was more than $110 \mathrm{~m}$ a.s.l. in the western part of the Baltic basin and up to 95 $\mathrm{m}$ a.s.l. in the eastern part (Fig. 1). In the southern part of the Baltic the water level was at least 15-16 $\mathrm{m}$ b.s.l, indicated by the peat accumulation in the Vistula and Pomeranian Bay (dated about $13600 \pm 510$ and $13800 \pm 120$ cal yr BP respectively; Uścinowicz, 2006), however there are only few data available. The water level at Öresund threshold was about $7 \mathrm{~m}$ b.s.l. (Björck, 1995). The water level isobases show a regular pattern of the uplift in NW, however, in the Lake Peipsi basin isobases curve towards SE, being up to $8 \mathrm{~m}$ higher than expected from the regional pattern. The Lake Peipsi basin was connected via Lake Vôrtsjärv basin with the Baltic Sea basin.

\subsection{BIL $13300 \mathrm{cal}$ yr BP $\left(A_{2}\right)$}

Modelling results indicate that in the northern part of the Baltic the water level lowered about 15 meters, being in the western part up to $100 \mathrm{~m}$ a.s.l. and in the eastern part up to $80 \mathrm{~m}$ a.s.l. (Fig. 2). Water level in the southern Baltic seems to be more stable, concluded from the decreased uplift rate and the BIL threshold, which located in the Öresund area. However, proxy data from the southern Baltic are limited. The water level isobases show a regular pattern of the uplift towards the NW direction, but in the Peipsi basin they curve towards SE similarly to $14000 \mathrm{cal}$ yr BP. The strait in the southern Estonia via Lake Voortsjärv still existed, but it was considerably narrowed. Reconstruction indicates that in NW Russia the BIL extended to the Lake Ladoga (Fig. 2).

\subsection{BIL 12200 cal yr BP (BI)}

During the standstill of the ice margin at the Salpausselkä I (SS I) the water level was up to 140-150 m 


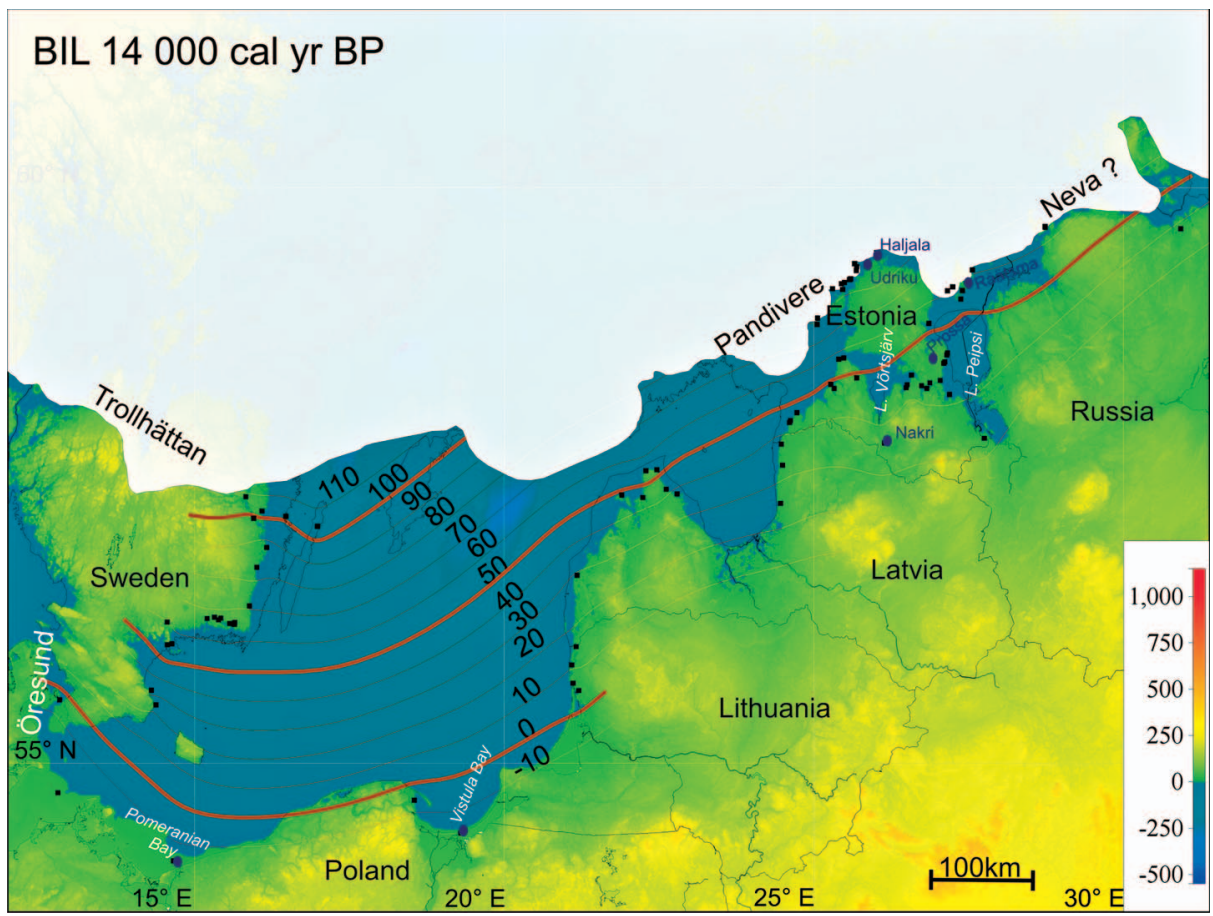

Fig. 1. Baltic Ice Lake palaeogeography about 14000 cal yr BP. Brown lines mark the modelled water level elevations in meters above sea level. Black squares mark the sites used for the modelling. Blue circles with names mark the radiocarbon-dated sites mentioned in the text.

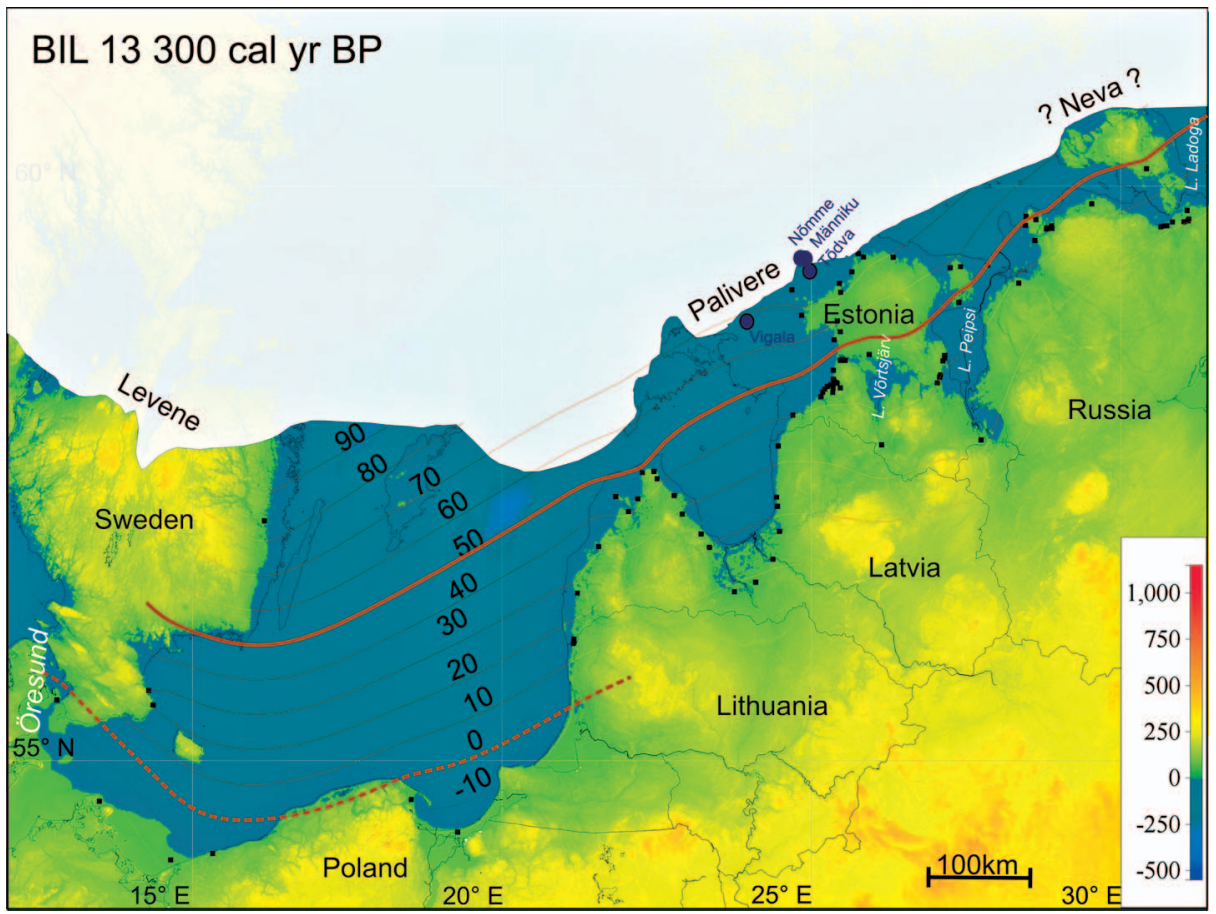

Fig. 2. Baltic Ice Lake palaeogeography about 13300 cal yr BP. Brown lines mark the modelled water level elevations in meters above sea level. Black squares mark the sites used for the modelling. Blue circles with names mark the sites mentioned in the text. 
a.s.l. in Finland, but below the present sea level near Lithuanian coast and further south (Fig. 3). Polish data indicate that the water level lowered significantly compared to the previous stage and the peat accumulation started at $25 \mathrm{~m}$ b.s.l ca $12350 \pm 250$ cal yr BP at Slupsk Bank (Uścinowicz, 2006). The peat accumulation occurred also at Southern Middle Bank (21 m b.s.l., dated $11950 \pm 220$ cal yr BP; Fig. $3)$, however there is disagreement with data from Latvia and Lithuania (Grinbergs, 1957; Gelumbauskaitë \& Šeèkus, 2005). In Estonia considerable rearrangement of the Lake Peipsi and Vortsjärv drainage system occurred: their connection with the BIL was terminated because of the land uplift and the lakes started to develop as isolated water bodies (Fig. 3). The lakes existed only in the northern parts of the Peipsi and Vortsjärv basins with their water levels being above the BIL water level about 3 and 6 $\mathrm{m}$ respectively. Lake Ladoga was still connected with the BIL.

\subsection{BIL 11700 cal yr BP (BIII)}

During the ice margin standstill at the Salpausselkä II (SS II) the water level was up to 150-160 m a.s.l. in Finland and Sweden (Fig. 4). In the southern Baltic the water level was more than $20 \mathrm{~m}$ below the present sea level, indicated by the peat accumulation at Slupsk Bank (Uscinowicz, 2006). The lakes still existed in the northern parts of the Peipsi and Võrtsjärv basins, but their water levels were now about 8 and $12 \mathrm{~m}$ above the BIL level. Lake Ladoga in NW Russia was connected with the BIL, however the strait in the Neva valley was narrowed and main connection existed over the Karelian Isthmus (Fig. 4).

\section{Discussion}

The highest shoreline of the BIL $\mathrm{A}_{1}$ in Estonia was formed concurrently with the formation of the

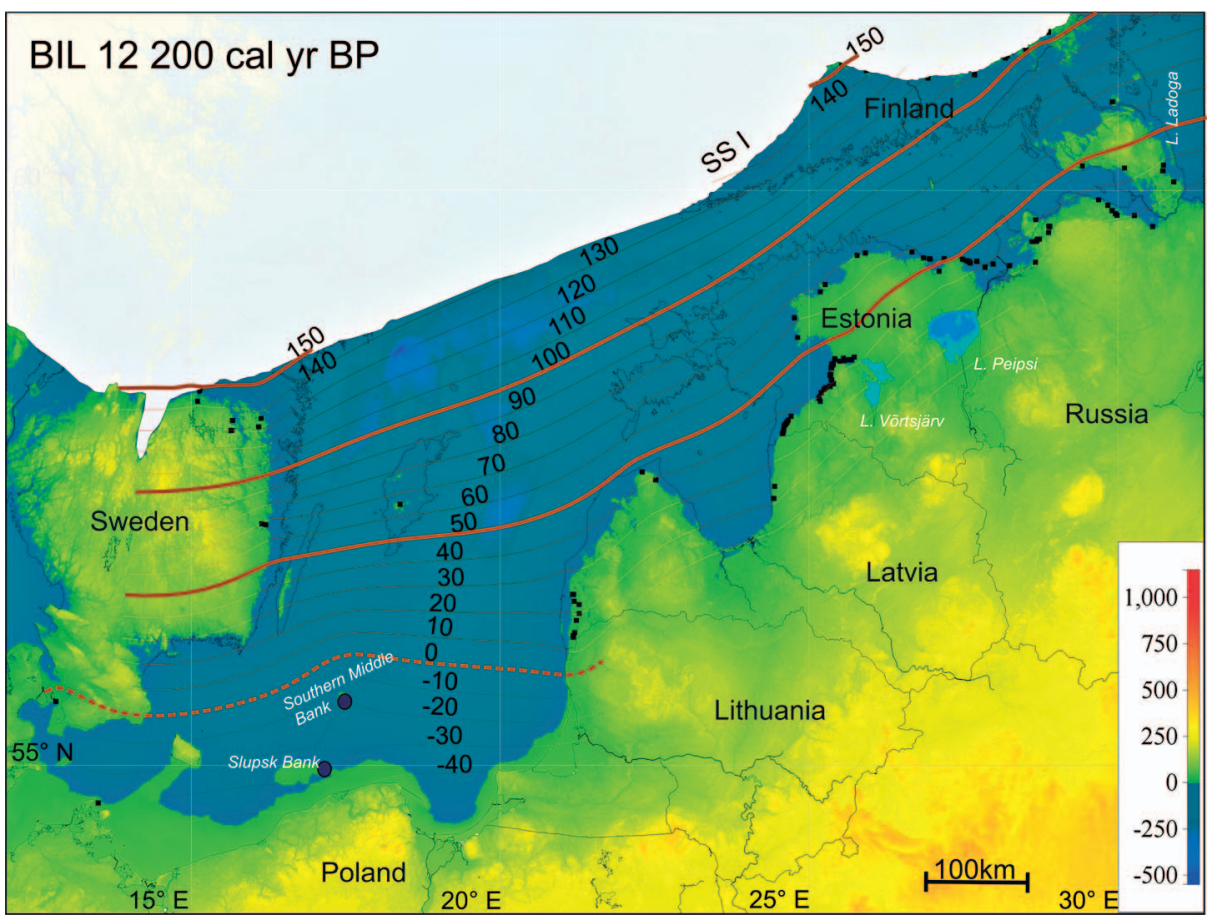

Fig. 3. Baltic Ice Lake palaeogeography about 12200 cal yr BP. Brown lines mark the modelled water level elevations in meters above sea level. Black squares mark the sites used for the modelling. Blue circles with names mark the radiocarbon-dated sites mentioned in the text. 


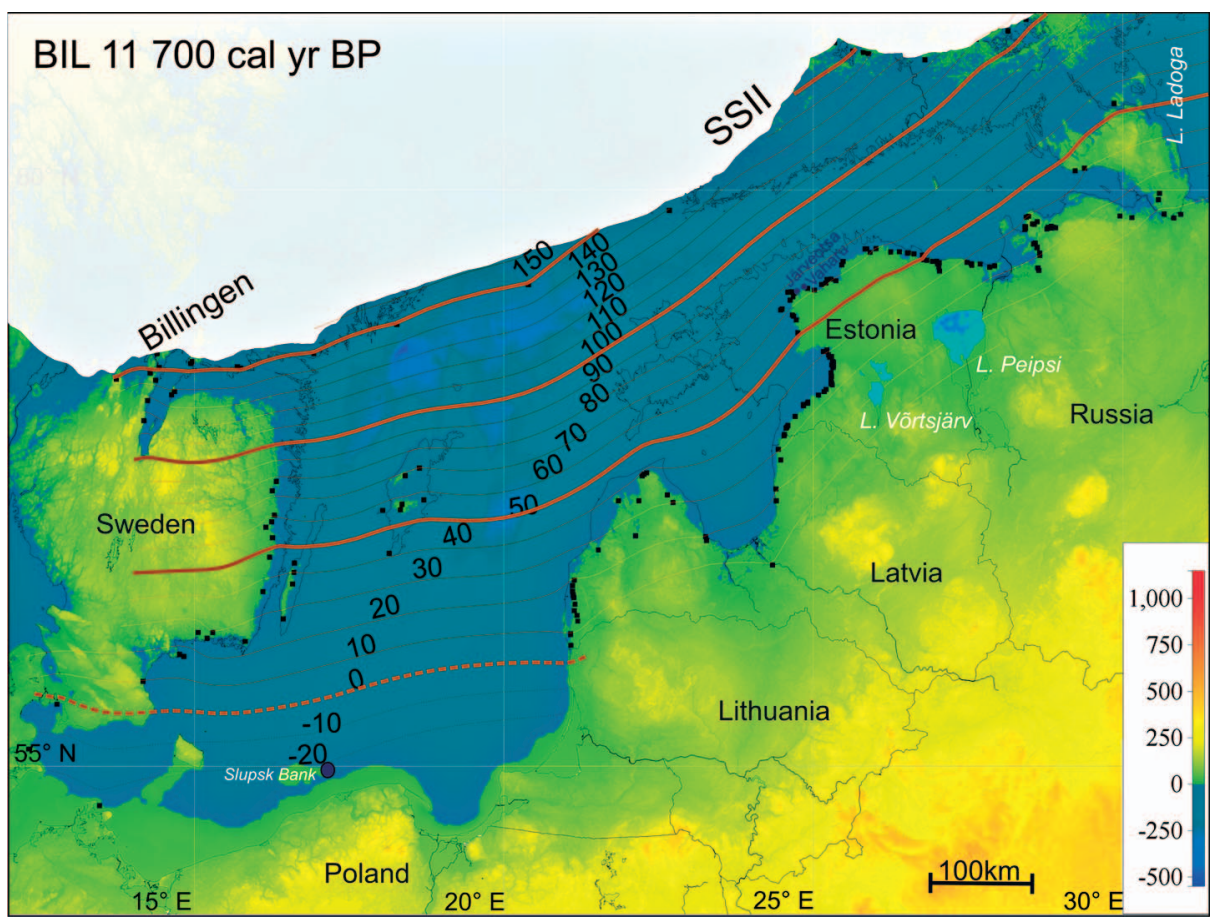

Fig. 4. Baltic Ice Lake palaeogeography about 11700 cal yr BP. Brown lines mark the modelled water level elevations in meters above sea level. Black squares mark the sites used for the modelling. Blue circles with names mark the radiocarbon-dated sites mentioned in the text.

Pandivere ice marginal zone (Fig. 1) and absence of the AMS $-{ }^{14} \mathrm{C}$ dates lead to correlate the Pandivere formation with the age of the Neva ice marginal zone ca $13300 \mathrm{cal}$ yr BP in NW Russia (Vassiljev et al., 2005). The age of the Neva zone was derived from the AMS radiocarbon dates of varved sediment from Lake Onega in Karelia, Russia (Saarnisto \& Saarinen, 2001). Latest palaeolake studies at Haljala and Udriku (Fig. 1), close to the proximal belt of the Pandivere zone, evidenced that deposition of

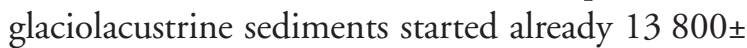
120 and $14050 \pm 190 \mathrm{cal} \mathrm{yr} \mathrm{BP}$, respectively (Saarse et al., 2009; Amon \& Saarse, 2010; Saarse et al., 2012a, b), suggesting that Pandivere stage and accordingly the BIL stage $A_{1}$ is older of that of the Neva ice-marginal formations. New age of the Pandivere belt is also indirectly supported by the AMS $-{ }^{14} \mathrm{C}$ dates $(14450 \pm 240 \mathrm{cal}$ yr BP) from Lake Prossa (Fig. 1), which locates on the Saadjärv drumlin field between the Otepää and Pandivere ice marginal zones (Kihno et al., 2011). The AMS${ }^{14} \mathrm{C}$ dates from Lake Nakri (Fig. 1), in front of the
Otepää marginal formations verify that this area was ice free before $13900 \pm 80$ cal yr BP (Amon et al., 2012). Furthermore, two conventional radiocarbon dates (13 900 \pm 130 and $13950 \pm 180$ cal yr BP; Ilves, 1980) from the bottom deposits of Lake Räätsma (Fig. 1), in front of the Pandivere ice margin, support the new age. Varve chronology studies (Hang et al., 2011) claimed the stagnation of the ice margin at the Pandivere zone within ca 13 800-13900 cal yr BP. But later authors have been declared that age of the Pandivere-Neva zone is tentatively 13 500-13 $300 \mathrm{cal}$ yr BP (Talviste et al., 2012).

The new age of the Pandivere ice marginal zone and the first stage of the BIL are in agreement with data from Sweden. Pandivere ice marginal formations were usually correlated with the Trollhättan moraine in Sweden (Lundqvist \& Saarnisto 1995; Fig. 1). However, after Lundqvist and Wohlfarth (2001) showed that the Trollhättan moraine formed about 14200 cal yr BP (11 800$\left.11900 \mathrm{C}^{14} \mathrm{yr} \mathrm{BP}\right)$, it made correlation with the 
Pandivere stage questionable last being about 900 years younger. The new age of the Pandivere stage about $13800-14000 \mathrm{cal} \mathrm{yr} \mathrm{BP}$ is in better agreement with the age of the Trollhättan than earlier, but in disagreement with the age of the Neva marginal belt (13 300 cal yr BP; Saarnisto \& Saarinen, 2001).

The age of the formation of the BIL stage $A_{2}$ (in Estonia) was earlier unclear, as it was considered to be in between the Pandivere and Palivere stades (Kessel \& Raukas, 1982). Rosentau et al. (2007, 2008, 2009) compared the water levels of the BIL in Estonia and Sweden and concluded that the BIL stage $A_{2}$ occurred before the first drainage of the BIL about 12800 cal yr BP (Svensson, 1991; Björck, 1995). That was equivalent to the age of the Palivere stade (12 700-12 800 cal yr BP; Kalm, 2006). However, that age was solely based on the floating varve chronology and 476 annual varved counts in Vigala section (Fig. 2), located between the Pandivere and Palivere belts (Hang \& Sandgren, 1996). Combining varve chronology and newly obtained age for the Pandivere belt, Palivere ice marginal zone was formed about $13200-13500 \mathrm{cal}$ yr BP. That age is supported by AMS dates from the Tôdva basin (Fig. 2) beyond the Palivere zone where sedimentation started about $13200 \pm 140 \mathrm{cal}$ yr BP (Saarse et al., 2012b). Estimated by OSL (Raukas \& Stankowski, 2005) and ${ }^{10}$ Be methods (Rinterknecht et al., 2006) ages of the Palivere belt sediments differ thousand of years and does not give reliable age for this belt. Our suggested timing of the Palivere ice marginal formations coincides with the deglaciation chronology of the southern Finland, according to which the retreating ice margin reached southern Finland ca 13 000-13 $100 \mathrm{cal}$ yr BP and the northern shore of the Gulf of Finland became ice free (Saarnisto \& Saarinen, 2001; Lunkka et al., 2004; Hyttinen, 2011; Johansson et al., 2011).

Palivere stage was earlier correlated with the Vimmerby moraine (Raukas, 1992) or with the Levene moraine (Berglund, 1979) in Sweden (Fig. 2). However, Lundqvist and Wohlfarth (2001) suggested that the Levene moraine formed around $13400 \mathrm{cal}$ yr BP, what was approximately the same age as the Pandivere-Neva ice margin - $13300 \mathrm{cal}$ yr BP (Kalm, 2006; Hang, 2003; Saarnisto \& Saarinen, 2001). Suggested new age of the Palivere stade is in good agreement with age of the Levene moraine (Lundqvist \& Wohlfarth, 2001) and comparable with the age of the Neva stade (NW Russia; Saarnisto \& Saarinen, 2001).

Earlier studies (Pärna, 1960; Kessel \& Raukas, 1982) affirmed that during the Palivere stade water level dropped about $30 \mathrm{~m}$ lower that of $\mathrm{A}_{2}$ water level. This conclusion was based on glaciofluvial flat plains near Tallinn, Männiku and Nómme (Fig. 2). OSL dates from Männiku sandy deposits did not offer a reliable age of their formation, varying between 80 500-10 000 years (Raukas \& Stankowski, 2005). The sedimentological studies at Salpausselkä I (Fyfe, 1990) showed that these low lying glaciofluvial plateau-like plains are overlapping fans formed below the water surface, what means that their surface did not mark the water level position. Most likely, above-mentioned plateau-like marginal formations in Estonia have also been deposited below the water surface. Linkrus (1976, 1981) suggested that glaciofluvial deltas south of the Palivere ice marginal formations are not the real deltas but fluvio-limnoglacial terraces as glaciofluvial plains smoothly return to limnoglacial ones. Wide distribution of subaqueous waterlain glacial diamiction formed during the Palivere stade 50-60 $\mathrm{m}$ below of the Baltic Ice Lake water table (Kalm \& Kadastik, 2001) could also serve as argument on the higher water level, during deposition of Palivere and Nómme marginal plains, than assumed earlier. In this case there was no low water level, what is actually difficult to explain with present knowledge on the light of absence of such low threshold in the Baltic basin.

The BIL stage BI existed during the formation of the Salpausselkä I moraines (Fig. 3), which age is based on the varve counts, AMS ${ }^{14} \mathrm{C}$ dates and palaeomagnetic measurements, proceeded about 12 300-12 100 cal yr BP (Saarnisto \& Saariainen, 2001), according to ${ }^{10} \mathrm{Be}$ dating $12500 \pm 700$ years (Rinterknecht et al., 2004) and according to revised varve chronology to $12260 \mathrm{cal}$ yr BP (Donner, 2010). 
The lowest modelled shoreline of the BIL is BIII (Fig. 4) which coastal formations correspond to the water level prior the Billingen (Sweden) drainage and the ice margin standstill at the Salpausselkä II about 11 800-11 600 cal yr BP (Saarnisto \& Saarinen, 2001). Two conventional radiocarbon dates from the bottom deposits of Lake Järveotsa $11900 \pm 180$ and $11850 \pm 240$ cal yr BP (Poska, 1994) refer to possibility that these sediments accumulated during BIII phase, just before the BIL drainage. But conventional radiocarbon date from Vaharu (12 105 \pm 280 cal yr BP) we consider too old, as it was done from the calcareous rich deposits (Sarv \& Ilves, 1970).

Ice margin retreat from Salpausselkä II belt have been correlated with the drainage of BIL at 11 $590 \pm 100$ (Saarnisto \& Saarinen, 2001) or 11560 (Andrén et al., 2002).

\section{Conclusions}

Based on lately obtained AMS- ${ }^{14} \mathrm{C}$ dates, the age of the BIL $A_{1}$ and $A_{2}$ stages in Estonia have been reassessed. BIL $A_{1}$ phase developed during 13800 $14000 \mathrm{cal} \mathrm{yr} \mathrm{BP}$ in front of the Pandivere ice margin. BIL $\mathrm{A}_{2}$ stage developed between 13200 $13500 \mathrm{cal} \mathrm{yr} \mathrm{BP}$ in front of Palivere ice margin. The new ages of the Estonian ice marginal zones are in good agreement with those from Sweden and Finland. Correlation with NW Russia suggests that age of the Palivere stade is most likely comparable with the Neva stade and age of the Pandivere stade is comparable with the Luga stade.

\section{Acknowledgements}

This study was supported by the Estonian Science Foundation grants ETF 8552, ETF 9031 and by Estonian target funding project SF0140021s12 and IUT1-8. We thank anonymous reviewer for valuable comments and suggestions.

\section{References}

Agrell, H. 1976. Highest coastline in south-eastern Sweden. Boreas 5, 143-154.

Amon, L. \& Saarse, L. 2010. Postglacial palaeoenvironmental changes in the area surroundings Lake Udriku in North Estonia. Geological Quarterly 54, 85-94.

Amon, L., Veski, S., Heinsalu, A. \& Saarse, L. 2012. Timing of Lateglacial vegetation dynamics and respective palaeoenvironmental conditions in southern Estonia: evidence from the sediment record of Lake Nakri. Journal of Quaternary Science 27, 169-180.

Andrén, T., Lindeberg, G. \& Andrén, E. 2002. Evidence of the final drainage of the Baltic Ice Lake and the brackish phase of the Yoldia Sea in glacial varves from the Baltic Sea. Boreas 31, 226-238.

Berglund, B.E. 1979. The deglaciation of southern Sweden 13,500-10,000 B.P. Boreas 8, 89-117.

Bitinas, A., Damušyte, A., Stančikaite, M. \& Aleksa, P. 2002. Geological development of the Nemunas River Delta and adjacent areas, West Lithuania. Geological Quarterly 46, 375-389.

Björck, S. 1995. A review of the history of the Baltic Sea, 13.08.0 ka BP. Quaternary International 27, 19-40.

Bronk Ramsey, C. 2008. Deposition models for chronological records. Quaternary Science Reviews 27, 42-60.

Bronk Ramsey, C. 2009. Bayesian analysis of radiocarbon dates. Radiocarbon 51, 337-360.

Donner, J. 1978. The dating of the levels of the Baltic Ice Lake and the Salpausselkä moraines in Southern Finland. Commentationes Physico-Mathematicae 48, 11-38.

Donner, J. 2010. The Younger Dryas age of the Salpausselkä moraines in Finland. Bulletin of the Geological Society of Finland 82, 69-80.

Fyfe, G.J. 1990. The effect of water depth on ice-proximal glaciolacustrine sedimentation: Salpausselkä I, southern Finland. Boreas 9, 147-164.

Gelumbauskaitë, L. \& Šeèkus, J. 2005. Late Quaternary shore formations of the Baltic basins in the Lithuanian sector. Geologija 52, 34-45.

Grinbergs, E.F. 1957. Late- and postglacial history of the coast of the Latvian SSR. Academy of Sciences of the Latvian SSR, Institute of Geology and Mineral Resources. Riga, 127 p. (in Russian).

Gudelis, V. 1979. The Quaternary history of the Baltic Lithuania. In: Gudelis, V. \& Königsson, L.-K. (eds.) The Quaternary History of the Baltic. Acta Universitatis Upsaliensis, Uppsala, 159-173.

Hang, T. 2003. A local clay-varve chronology and postglacial sedimentary environment in glacial Lake Peipsi, eastern Estonia. Boreas 32, 416-426.

Hang, T., Ojala, A., Kohv, M. \& Tuvikene, T. 2011. Varve chronology and proglacial sedimentary environment in Pärnu area western Estonia. In: Johansson, P., Lunkka, J.P. \& Sarala, P. (eds.) Late Pleistocene Glacigenic Deposits from the Central part of the Scandinavian Ice Sheet to Younger Dryas End Moraine Zone. Geological Survey of Finland, Rovaniemi, 94-95.

Hang, T. \& Sandgren, P. 1996. Magnetostratigraphy of varved 
clays. In: Meidla, T., Puura, I., Nemliher, J., Raukas, A. \& Saarse, L. (eds.) The Third Baltic Stratigraphic Conference. Abstracts. Field Guide. Tartu, pp. 152-154.

Hyvarinen, H. 1973. The deglaciation history of eastern Fennoscandia-recent data from Finland. Boreas 2, 85102.

Hyyppä, E. 1943. Itämeren historia uusimpien Itä-Karjalassa suoritettujen tutkimusten valossa (Föredragsrefereat: Östersjöns historia i ljuset av de nyaste forskningar i ÖstKarelen). Terra 55, 122-127.

Hyttinen, O., Kotilainen, A. \& Salonen, V.-P. 2011. Acoustic evidence of a Baltic Ice lake drainage debrite in the northern Baltic Sea. Marine Geology 284, 139-148.

Ilves, E. 1980. Tartu radiocarbon dates X. Radiocarbon 22, 1084-1089.

Jakobsson, M., Björck, S., Alm, G., Andrén, T., Lindeberg, G. \& Svensson, N.-O. 2007. Reconstructing the Younger Dryas ice dammed lake in the Baltic Basin: bathymetry, area and volume. Global and Planetary Change 57, 355370.

Jarvis A., H.I. Reuter, A. Nelson, E. Guevara, 2008, Hole-filled seamless SRTM data V4, International Centre for Tropical Agriculture (CIAT), available from http://srtm.csi. cgiar.org.

Johansson, P., Lunkka, J.P. \& Sarala, P. 2011. The Glaciation of Finland. In: Ehlers, J., Gibbard, P.L. \& Hughes, P.D (eds.) Quaternary Glaciations - extent and Chronology. A closer look. Amsterdam, The Netherlands, pp. 105-114.

Kalm, V. 2006. Pleistocene chronostratigraphy in Estonia, southeastern sector of the Scandinavian glaciation. Quarternary Science Reviews 8, 960-975.

Kalm, V. \& Kadastik, E. 2001. Waterline glacial diamicton along the Palivere ice-marginal zone on the West Estonian Archipelago, Eastern Baltic Sea. Proceedings of the Estonian Academy of Sciences, Geology 50, 114-127.

Kalm, V., Raukas, A., Rattas, M. \& Lasberg, K. 2011. Pleistocene Glaciations in Estonia. In: Ehlers, J., Gibbard, P.L. \& Hughes, P.D. (eds.) Quaternary Glaciations - extent and Chronology. A closer look. Amsterdam, The Netherlands, pp. 95-104.

Kessel, H. \& Raukas, A. 1979. The Quaternary History of the Baltic. Estonia. In: Gudelis, V. \& Königsson, L.-K. (eds.) The Quaternary History of the Baltic. Acta Universitatis Upsaliensis, Uppsala, pp. 127-146.

Kessel, H. \& Raukas, A. 1982. On geological development of the Baltic Sea in Late- Glacial time on the basis of the east Baltic evidence. Peribaltic II, 131-143. (in Russian).

Kihno, K., Saarse, L. \& Amon, L. 2011. Late Glacial vegetation, sedimentation and ice recession chronology in the surroundings of Lake Prossa, central Estonia. Estonian Journal of Earth Sciences 60, 147-158.

Kvasov, D.D. 1979. The Late-Quaternary history of large lakes and inland seas of Eastern Europe. Annales Academiae Scientiarum Fennicae, Series A. III, Geologica-
Geographica, 1-71.

Leverington, D.W., Teller, J.T. \& Mann, J.D. 2002. A GIS method for reconstruction of late Quaternary landscapes from isobase data and modern topography. Computers $\&$ Geosciences 28, 631-639.

Linkrus, E. 1976. The geomorphology and landscape regions of Lahemaa National Park. In: Raukas, A. \& Tulp, L. (eds.) Estonia. Regional studies, Estonian Geographical Society, Tallinn, pp. 114-126.

Linkrus, E. 1981. Geomorphology of the eastern part of the Lahemaa National Park. In: I. Etverk, I. (ed.) Lahemaa uurimused. Valgus, Tallinn, 28-44 (in Estonian).

Lundqvist, J \& Saarnisto, M, 1995. Summary of project IGCP 25. Quaternary International 28, 9-18.

Lundqvist, J. \& Wohlfarth, B. 2001. Timing and east-west correlation of south Swedish ice marginal lines during the Late Weichselian. Quaternary Science Reviews 20, 1127 1148.

Lunkka, J.P., Johansson, P., Saarnisto, M. \& Sallasmaa, O. 2004. Glaciations of Finland. In: Ehlers, J. \& Gibbard P.L. (eds.) Quaternary Glaciations - Extent and Chronology. Part I: Europe. Elsevier, Amsterdam, pp. 93-100.

Markov, K.K. 1931. The development of the relief in the northwestern part of the Leningrad district. Trudy Glavnogo geologo-razvedochnogo upravlenija VSNH SSSR 117, 256 p. (in Russian)

Miidel, A. 1995. An attempt to apply trend-surface analysis to the study of raised shorelines of the Baltic Sea in Estonia. Proceedings of the Academy of Sciences, Geology 44, 97-110.

Munthe, H. 1910. Studies in the Late-Quaternary history of Southern Sweden. Geologiska föreningens i Stockholm förhandlingar 32, 1197-1292.

Poska, A. 1994. Three pollen diagrams from Coastal Estonia. Kvartärgeologiska Avdelningen. Uppsala University, Licentiate Thesis 170, Uppsala-Tallinn, 40 p.

Pärna, K. 1960. Zur Geologie des Baltischen Eisstausees Sowie der Lokalen Grossen Eisstauseen auf dem Territorium der Estnischen SSR. Eesti NSV Teaduste Akadeemia Geoloogia Instituudi Uurimused V, 269-278. (in Russian with German summary)

Ramsay, W. 1917. De s.k. marine gränserna i södra Finland. Fennia 16, 1-151.

Ramsay, W. 1928. Eisgestaute Seen und Rezession des Inlandeises in Südkarelien und im Nevatal. Fennia 50, $1-21$.

Ramsay, W. 1929. Niveaurschiebungen, Eisgestaute Seen und Rezession des Inlandeises in Estland. Fennia 52, 1-48.

Rasmussen, S.O., Andersen, K.K., Svensson, A.M., Steffensen, J.P., Vinther, B., Clausen, H.B., Siggaard-Andersen, M.L., Johnsen, S.J., Larsen, L.B., Dahl-Jensen, D., Bigler, M., Röthlisberger, R., Fischer, H., Goto-Azuma, K., Hansson, M. \& Ruth, U. 2006. A new Greenland ice core chronology for the last glacial termination. Journal of 
Geophysical Research 111, 1-16.

Raukas, A. 2004. Application of OSL and ${ }^{10} \mathrm{Be}$ techniques to the establishment of deglaciation chronology in Estonia. Proceedings of the Estonian Academy of Sciences, Geology 53, 267-287.

Raukas, A. \& Stankowski, W. 2005. Influence of sedimentological composition on OSL dating of glaciofluvial deposits: examples from Estonia. Geological Quarterly 49, 463-470.

Rinterknecht, V. R., Clark, P.U., Raisbeck, G.M., Yiou, F., Brook, E.J., Tschudi, S. \& Lunkka J.P. 2004. Cosmogenic $10 B e$ dating of the Salpausselkä I Moraine in southwestern Finland. Quaternary Science Reviews 23, 2283-2289.

Rinterknecht, V. R., Clark, P.U., Raisbeck, G.M., Yiou, F., Bitinas, A., Brook, E.J., Marks, L., Zelčs, V., Lunkka, J.P., Pavlovskaya, I.E., Piotrowski, J.A. \& Raukas, A. 2006. The Last Deglaciation of the Southeastern Sector of the Scandinavian Ice Sheet. Science 311, 1449-1452.

Reimer, P. J., Baillie, M. G. L., Bard, E., Bayliss, A., Beck, J. W., Blackwell, P. G., Bronk Ramsey, C., Buck, C. E., Burr, G. S., Edwards, R. L., Friedrich, M., Grootes, P. M., Guilderson, T. P., Hajdas, I., Heaton, T. J., Hogg, A. G., Hughen, K. A., Kaiser, K. F., Kromer, B., McCormac, F. G., Manning, S. W., Reimer, R. W., Richards, D. A., Southon, J. R., Talamo, S., Turney, C. S. M., van der Plicht, J., \& Weyhenmeyer, C. E. 2009. IntCal09 and Marine09 radiocarbon age calibration curves, 0-50,000 years cal BP. Radiocarbon 51, 1111-1150.

Rosentau, A., Vassiljev, J., Saarse, L. \& Miidel, A. 2007. Palaeogeographic reconstruction of proglacial lakes in Estonia. Boreas 36, 211-221.

Rosentau, A., Vassiljev, J., Saarse, L. \& Miidel, A. 2008. Proglacial lake shorelines of Estonia and adjoining areas. Polish Geological Institute Special Papers 23, 81-86.

Rosentau, A., Vassiljev, J., Hang, T., Saarse, L. \& Kalm, V. 2009. Development of the Baltic Ice Lake in the eastern Baltic. Quaternary International 206, 16-23.

Saarnisto, M., Grönlund, T. \& Ekman, I. 1995. Lateglacial of Lake Onega - Contribution to the history of the eastern Baltic basin. Quaternary International 27, 111-120.

Saarnisto, M. \& Saarinen T. 2001. Deglaciation chronology of the Scandinavian Ice Sheet from the Lake Onega Basin to the Salpausselkä End Moraines. Global Planetary Change 31, 387-405.

Saarse, L., Heinsalu, A. \& Veski, S. 2012a. Deglaciation chronology of the Pandivere and Palivere ice-marginal zones in Estonia. Geological Quarterly 56, 353-362.

Saarse, L., Heinsalu, A., Veski, S., Amon, L. \& Gaidamavicus, A. 2012b. On the deglaciation chronology of the Palivere ice-marginal zone, northern Estonia. Bulletin of the Geological Society of Finland 84, 21-31.
Saarse, L., Niinemets, E., Amon, L., Heinsalu, A., Veski, S. \& Sohar, K. 2009. Development of late glacial Baltic basin and the succession of vegetation cover as revealed at Palaeolake Haljala, northern Estonia. Estonian Journal of Earth Sciences 58, 317-333.

Saarse, L., Vassiljev, J. \& Miidel, A. 2003. Simulation of the Baltic Sea Shorelines in Estonia and Neighboring areas. Journal of Coastal Research 19, 261-268.

Saarse, L., Vassiljev, J., Rosentau, A. \& Miidel, A. 2007. Reconstructed late glacial shore displacement in Estonia. Baltica 20, 35-45.

Sarv, A. \& Ilves, E. 1970. Radiocarbon dating of bog-lacustrine deposits of the Vaharu Bog (north-western Estonia). In: Bartosh, T. (ed.) Palynological studies in Peribaltic. Riga, Zinatne, pp. 143-149. (in Russian with English summary)

Sauramo, M. 1958. Die Geschichte der Ostsee. Annales Academiae Scientiarum Fennicae, Ser. A III, GeologicaGeographica 51, 1-522.

Seifert, T.T., Tauber, F. \& Kayser, B. 2001. A high resolution spherical grid topography of the Baltic Sea $-2^{\text {nd }}$ edition. In: Baltic Sea Science Congress 2001: past, present and future - a joint venture. Stockholm Marine Research Centre, Stockholm University, p. 298.

Svensson, N.-O. 1989. Late Weichselian and Early Holocene shore displacement in the central Baltic, based on stratigraphical and morphological records from eastern Småland and Gotland, Sweden. LUNDQUA Thesis 25, $195 \mathrm{p}$.

Svensson, N.-O. 1991. Late Weichselian and Early Holocene shore displacement in the central Baltic Sea. Quaternary International 9, 7-26.

Talviste, P., Hang, T. \& Kohv, M. 2012. Glacial varves at the distal slope of Pandivere-Neva ice-recessional formations in western Estonia. Bulletin of the Geological Society of Finland 84, 7-19.

US Geological Survey, 1996. GTOPO30 Global 30 arc elevation data. EROS http://edc.usgs.gov/products/ elevation/gtopo30/gtopo30.html

Uścinowicz, S. 2006. A relative sea-level curve for the Polish Southern Baltic Sea. Quaternary International 145-146, 86-105.

Vassiljev, J., Saarse, L. \& Miidel, A. 2005. Simulation of proglacial shore displacement in Estonia. Geological Quarterly 49, 253-262.

Vassiljev, J., Saarse, L. \& Rosentau, A. 2011. Palaeoreconstruction of the Baltic Ice Lake in the eastern Baltic. In: Harff, J., Björck, S. \& Hoth, P. (eds.) The Baltic Sea Basin. Springer-Verlag, Berlin, pp. 189-202.

Veinbergs, I. 1979. The Quaternary history of the Baltic. Latvia. In: Gudelis, V., \& Königsson, L.-K. (eds.) The Quaternary history of the Baltic. Acta Universitatis Upsaliensis. Uppsala, 147-157. 